\title{
Molecular phylogeny and biogeographic history of the piculets (Piciformes: Picumninae)
}

\author{
Jérôme Fuchs, Jan I. Ohlson, Per G. P. Ericson and Eric Pasquet
}

Fuchs, J., Ohlson, J. I., Ericson, P. G. P. and Pasquet, E. 2006. Molecular phylogeny and biogeographic history of the piculets (Piciformes: Picumninae). - J. Avian Biol. 37: $487-496$.

\begin{abstract}
The subfamily Picumninae (piculets) includes 3 genera and 30 species of tiny and shorttailed woodpeckers with a pantropical distribution. Within the Picumninae, two cases of intercontinentally disrupted distributions at the genus level occur. The first one concerns the genus Sasia (one species in Africa and two in southeast Asia) while the second concerns Picumnus (one species in southeast Asia and 25 in South America). These disrupted distributions, as well as several morphological differences, have lead some authors to place the African representative of Sasia and the southeast Asian representative of Picumnus in their own monotypic genera (Verreauxia and Vivia, respectively). To address the taxonomic status and biogeographic history of the piculets, we sequenced 2676 bp of DNA from one mitochondrial (ND2) and two nuclear markers (myoglobin intron 2 and $\beta$-fibrinogen intron 7). Monophyly of Picumninae could not be recovered with confidence, while monophyly of Sasia and Picumnus were always strongly supported. Molecular dating analyses revealed that the splits both between the African and Indo-Malayan Sasia and between the New World and Old World Picumnus occurred at ca 7.9 Myr BP. This time corresponds to the beginning of the formation of the northern Hemisphere ice sheets and the accompanying expansion of grasslands throughout the world. The spread of open areas in the northern parts of Eurasia and America prevented gene flow between tropical forest birds, such as the piculets, in Africa, southeast Asia and South America, respectively.
\end{abstract}

\begin{abstract}
J. Fuchs (correspondence) and E. Pasquet, UMR5202, Origine, Structure et Evolution de la Biodiversité, Département Systématique et Evolution, Muséum National d'Histoire Naturelle, 55 Rue Buffon, 75231 Paris, France, and Service Commun de Systématique Moléculaire, IFR CNRS 101, Muséum National d'Histoire Naturelle, 43, rue Cuvier, 75005 Paris, France. E-mail: fuchs@mnhn.fr. Jan I. Ohlson and P. G. P. Ericson, Department of Vertebrate Zoology and Molecular Systematics Laboratory, Swedish Museum of Natural History, P.O. Box 50007, SE-104 05 Stockholm, Sweden.
\end{abstract}

The avian subfamily Picumninae (Picidae) includes 30 species of small $(9-11 \mathrm{~cm})$ and short-tailed woodpeckers that are distributed in the tropics (Dickinson 2003). These birds climb tree trunks and mainly feed on ants and other small insects, or on large larvae. Current classification recognizes three genera in Picumninae, Picumnus, Sasia and Nesoctites (Dickinson 2003). Twenty-five out of the 26 recognized species in the genus Picumnus occur in South America while the remaining species, the speckled piculet $P$. innominatus, is endemic to southeast Asia. The South American species of
Picumnus form an assemblage of closely related species and superspecies that is supposed to have diversified recently, as inferred from their potential of interbreeding (Winkler and Christie 2002). The Asian species innominatus shares a synapomorphic tail pattern as well as a derived origin of the musculus serratus anterior (first thoracic rib only versus first thoracic rib and last cervical in other woodpeckers) with the New World members of Picumnus (Goodge 1972, Short 1982, Winkler and Christie 2002). The geographic distribution of Picumnus is unusual among birds and may only be paralleled in the

JOURNAL OF AVIAN BIOLOGY 
genera Celeus (Picidae) and Spizaetus (Accipitridae). Based mainly on the wide gap in geographic distribution the speckled piculet has sometimes been placed in a separate genus, Vivia Hodgson, 1837 (Wolters 19751982).

The Old World genus Sasia constitutes another example of an intercontinental distribution in Picumninae. Two of the three species of Sasia occur in tropical Asia (abnormis and ochracea), while the third is found in African rain forests (africana). The members of Sasia share several distinctive morphological features (e.g. bare area around the eye, round cross-section of the upper mandible) and the monophyly of the genus has never been questioned (Short 1982, Winkler and Christie 2002). Nevertheless, some peculiar morphological variation also occur: Sasia abnormis and S. ochracea have ten tail feathers and lack the first toe, while $S$. africana has eight tail feathers and a first toe (albeit greatly reduced; Short 1988). Historically the African representative has been placed in a separate genus, Verreauxia Hartlaub, 1856 (Peters 1948).

The third genus of piculets is Nesoctites, which includes one species living on Hispaniola in the Antilles. This species is larger than the other piculets but shares with them the soft plumage, short bill and short tail. Other anatomical data indicate that Nesoctites may be closer to the Picinae than to other Picumninae (Goodge 1972).

The piculets constitutes a group of birds with a highly interesting pattern of geographic distribution. A phylogenetic analysis of their relationships is expected to shed light on the evolution and biogeographic history of tropical forest birds in South America, Africa and southeast Asia. No such study have yet been published although Webb and Moore (2005) included three species of piculets (Sasia abnormis, Picumnus aurifrons and $P$. cirratus) in their molecular analysis. The results indicated that $S$. abnormis and the two Picumnus ( $P$. aurifrons and $P$. cirratus) had been separated for a long period of time, but little biogeographic information can be extracted from that because of the sparse taxon sampling.

Herein, we study the relationships among piculets by using $2,676 \mathrm{bp}$ obtained from two nuclear markers (myoglobin intron 2 and $\beta$-fibrinogen intron 7) and a mitochondrial protein-coding gene (ND2).

\section{Material and methods}

\section{Taxonomic sampling}

We sampled representatives of each biogeographic unit (Africa, Asia, South America). Unfortunately, we could not obtain any sample of the Antillean piculet Nesoctites micromegas. Several individuals were sequenced for the Old World taxa in order to investigate intra- specific variability in the two genetic markers. We also included in our study several representatives of the Picinae in order to test the monophyly of the Picumninae and obtain independent data on inter-generic distances. We sampled Picinae genera from the three main clades of woodpeckers highlighted by Webb and Moore (2005). Trees were rooted with a representative of the honeyguides (Indicator minor, Indicatoridae), a family suggested to be the sister-group of the Picidae (Simpson and Cracraft 1981, Swierczewski and Raikow 1981, Sibley and Ahlquist 1990, Johansson and Ericson 2003, Webb and Moore 2005). Identifications and geographic origins of the samples and GenBank accession numbers are given in Table 1.

\section{Laboratory procedure}

We extracted DNA from frozen or alcohol preserved tissues (blood, liver, muscle) using a CTAB-based protocol (Winnepenninckx et al. 1993) with an overnight Proteinase K $\left(0,1 \mathrm{mg} \cdot \mathrm{ml}^{-1}\right)$ digestion. Myoglobin intron 2 was amplified with primers $\mathrm{Myo} 2$ or $\mathrm{Myo} 2 \mathrm{Pi}-$ F (5' CCT GTC AAA TAT CTG GAG GTA TG 3', this study), and Myo3F (Heslewood et al. 1998, Slade et al. 1993). The whole ND2 gene was amplified with primers L5219-Met and H6313-Trp for most of the samples (Sorenson et al. 1999). Additional primers, (L5758-ND2, H6681-CO1, Sorenson et al. 1999) were used for some samples that were difficult to amplify or sequence with L5219-Met and H6313-Trp. $\beta$-fibrinogen intron 7 was amplified with primers FIB-B17U and FIB-B17L (Prychitko and Moore 1997). The thermocycling conditions followed standard procedures for these genes (Prychitko and Moore 1997, Fuchs et al. 2004). Three microliters of the amplification products were electrophoresed on $1,5 \%$ agarose gel and visualized under UV light with ethidium bromide to check for the correct fragment size and to control for the specificity of the amplifications. PCR products were purified directly using the QiaQuick PCR Purification Kit (Qiagen, Holden, Germany) and cycle-sequenced using the CEQ Dye Terminator Cycle Sequencing kit (Beckman Coulter, Inc, Fullerton, CA, USA) or the 'BigDye ${ }^{\circledR}$ Terminator Cycle Sequencing Kit' (Applied Biosystems) in both forward and reverse directions with the same primers used for PCR amplifications, and finally ran on an automated CEQ2000 DNA Analysis System sequencer (Beckman Coulter, Inc, Fullerton, CA, USA) or an ABI PRISM ${ }^{\circledR} 3100$ automated sequencer (Applied Biosystems). We obtained sequences from both strands of DNA for all taxa.

No length variations between alleles were detected for myoglobin intron 2 and â-fibrinogen intron 7 . The occurrence of single nucleotide polymorphism (SNP) in the myoglobin intron 2 and $\beta$-fibrinogen intron 7 
Table 1. List of taxa studied (following Dickinson 2003), tissue or voucher number and GenBank accession numbers. Abbreviations: AMNH, American Museum of Natural History, New York; LSUMZ, Museum of Natural Science, Louisiana State University; MNHN, Muséum National d'Histoire Naturelle, Paris; NRM, Swedish Museum of Natural History, Stockholm; ZMCU, Zoological Museum University of Copenhagen. References: 1 and 2; Prychitko and Moore (2000, 2003), and 3; Weibel and Moore (2002).

\begin{tabular}{|c|c|c|c|c|c|c|}
\hline Species & Family & Sample no. & Origin & Myoglobin & Fibrinogen & ND2 \\
\hline \multicolumn{7}{|l|}{ Ingroup } \\
\hline Campephilus haematogaster & Picidae & ZMUC 114730 & Ecuador & DQ188143 & AF240016 ${ }^{1}$ & DQ188169 \\
\hline Campethera caroli & Picidae & MNHN 03-04 & Cameroon & DQ188157 & DQ188131 & DQ188183 \\
\hline Colaptes auratus & Picidae & AMNH PAC820 & USA & DQ188152 & AY082398 ${ }^{2}$ & DQ188178 \\
\hline Dendrocopos leucotos & Picidae & NRM 996095 & Sweden & DQ188142 & DQ188116 & DQ188168 \\
\hline Dendrocopos major & Picidae & MNHN C29 & France & DQ188153 & DQ188127 & DQ188179 \\
\hline Dendrocopos minor & Picidae & NRM 986593 & Sweden & DQ188154 & AF $394321^{3}$ & DQ188180 \\
\hline Dryocopus martius & Picidae & MNHN C30 & France & DQ188140 & DQ188114 & DQ188166 \\
\hline Jynx torquilla & Picidae & MNHN 15-03 & China & DQ188146 & DQ188120 & DQ188172 \\
\hline Picoides mixtus & Picidae & NRM 976765 & Paraguay & DQ188151 & AF394323 ${ }^{3}$ & DQ188177 \\
\hline Picoides tridactylus & Picidae & ZMUC 115007 & Poland & DQ188138 & AF394332 3 & DQ188164 \\
\hline Picumnus aurifrons & Picidae & & & & AY082399 ${ }^{2}$ & \\
\hline Picumnus cirratus & Picidae & NRM 996693 & Paragu: & AY81 & DQ188124 & AY816227 \\
\hline Picumnus innominatus chinensis & Picidae & MNHN 18-46 & China & DQ & DQ188121 & 88173 \\
\hline Picumnus innominatus malayorum & Picidae & MNHN 4-2H & Thailand & DQ188145 & DQ188119 & DQ188171 \\
\hline Picumnus innominatus malayorum & Picidae & MNHN 31-92 & Lao RDP & DQ188144 & DQ188118 & DQ188170 \\
\hline Picumnus rufiventris & Picidae & 114884 & Ecuador & & DQ & 8167 \\
\hline Picumnus temminckii & Picidae & ZMUC 115783 & Paraguay & DQ188139 & DQ188113 & DQ188165 \\
\hline Picus canus & Picidae & MNHN 05-09 & Lao RDP & DQ188156 & DQ188130 & DQ188182 \\
\hline Picus viridis & Picidae & MNHN C38 & France & DQ1 & DQ1 & DQ188181 \\
\hline Sasia abnormis & Picidae & LSUMZ B-36428 & Malaysia & DQ188137 & DQ188111 & DQ188163 \\
\hline Sasia africana & Picidae & MNHN 02-36 & Cameroon & DQ188148 & DQ188122 & DQ188174 \\
\hline Sasia africana & Picidae & MNHN 03-05 & Cameroon & DQ188149 & DQ188123 & DQ188175 \\
\hline Sasia ochracea & Picidae & MNHN 4-2F & Thailand & DQ188134 & DQ188108 & DQ188160 \\
\hline Sasia ochracea & Picidae & MNHN 4-2G & Thailand & DQ1 & DQ1 & DQ188159 \\
\hline Sasia o & & NRM 947313 & Vietnam & & DQ1 & 8162 \\
\hline Sasia ochracea & Picidae & MNHN 05-43 & Lao RDP & DQ188135 & DQ188109 & DQ188161 \\
\hline \multicolumn{7}{|l|}{ Outgroup } \\
\hline Indicator minor & Indicatoridae & ZMUC 115456 & Tanzania & DQ188132 & DQ188106 & DQ188158 \\
\hline
\end{tabular}

sequences was suggested by the presence of double peaks. Those double peaks were coded using the appropriate IUPAC code. Absence of insertions, deletions and stop-codons in the reading frame of the protein-coding ND2 gene suggests that we did not amplify nuclear pseudogenes (Sorenson and Quinn 1998).

Multiple alignments of intron sequences were accomplished by hand modification after an initial alignment by Sequencher 4.1 (Gene Codes Corporation, Ann Arbor, MI, USA). Alignment of indels was straightforward for the two nuclear introns and indicated the presence of several insertion-deletions events ( 8 and 32 for myoglobin intron 2 and $\beta$-fibrinogen intron 7 , respectively) among which 1 and 21 (myoglobin intron 2 and $\beta$-fibrinogen intron 7 , respectively) were potentially informative. One region in the $\beta$-fibrinogen intron 7 sequences (nucleotides $461-473$ in our alignment) was excluded for the phylogenetic analyses because it could not been aligned unambiguously. The alignments of the nuclear introns have been deposited in the EMBL database (accession numbers ALIGN_000924 and ALIGN_000925 for myoglobin intron 2 and $\beta$-fibrinogen intron 7, respectively). Gaps were treated as missing data in the analyses.

\section{Phylogenetic analyses}

Phylogenetic trees were estimated using parsimony $(\mathrm{P})$, maximum likelihood (ML) and Bayesian inferences (BI) as implemented in PAUP* 4.0b10 (Swofford 2001) and MrBayes v. 3.0 (Huelsenbeck and Ronquist 2001). Likelihood models and parameters were estimated with Modeltest v. 3.6 (Posada and Crandall 1998), and MrModeltest (Nylander 2004) using the AIC criterion. $\mathrm{P}$ and $\mathrm{ML}$ analyses were performed using the heuristic tree bisection and reconnection branch-swapping (TBR) with 100 and 10 random addition replicates, respectively. Nodal support for $\mathrm{P}$ and ML was calculated using the non-parametric bootstrap (Felsenstein 1985; 1,000 and 100 replicates, respectively). ML bootstrap replicates were performed using PHYML (Guindon and Gascuel 2003). The three different gene regions we sequenced differ considerably in their properties and substitution dynamics (see results), we therefore did not perform combined ML and Bayesian analyses that assume a single model of evolution for the whole dataset. Accordingly, Bayesian analyses for the combined data set were performed freeing different parameters (base frequencies, rate matrix, shape parameter, proportion of in variable sites) to vary between the three partitions (ND2, myoglobin intron 2, $\beta$-fibrinogen intron 7). Four 
Metropolis-coupled MCMC chains (three heated and cold) were run for $2 \times 10^{6}$ generations with trees sampled every 100 generations. The first 200,000 generations (2,001 trees) were discarded ('burn-in' period) and the posterior probabilities were estimated for the remaining saved generations. Three independent Bayesian runs initiated from random starting trees were performed for each data set and the log-likelihood values and posterior probabilities were checked to ascertain that the chains had reached stationarity.

\section{Estimation of divergence times}

Only a few fossils have been assigned to the woodpeckers so far. The earliest fossil record from the Pici (barbets and toucans, honeyguides, piculets and woodpeckers), a fragmentary distal end of a tarsometatarsus, is dated to be from the lower Oligocene of Belgium (Mayr and Smith 2001). Mayr (2001) also described a tarsometatarsus from the late Oligocene of Germany that closely resembles in size and proportions that of a cardinal woodpecker Dendropicos fuscescens. However, in both cases, a reliable assignment to any of the Pici family is not possible (Mayr 2001, Mayr and Smith 2001). A fossil feather preserved in amber constitutes thus the earliest fossil clearly assigned to the woodpecker family Picidae (Laybourne et al. 1994). This feather was identified to be closely related to the Antillean piculet Nesoctites micromegas and estimated to be at least from the early Miocene (23.8 Myrs BP) and maximally from the upper Eocene (54.8 Myrs BP; Laybourne et al. 1994). The fact that we lack tissue of the Antillean Piculet prevented us to use this calibration point, even for specifying a minimum age for the Picinae-Picumninae split (see Results and Discussion). Instead, we used a calibration point based on biogeographic evidences. The calibration point used was the split between Sasia ochracea and $S$. abnormis. The distributional ranges of $S$. ochracea and $S$. abnormis are delimited by the Isthmus of Kra. Two important Isthmus of Kra Seaways probably occurred in the early Middle Miocene (24-13 Myrs $\mathrm{BP}$ ), and in the early Pliocene (5.5-4.5 Myr BP; Woodruff 2003). These seaways would have separated the Sundaic and Indochinese biotas by a $30-100 \mathrm{kms}$ wide gap of sea. Piculets are morphologically characterized by their very small size and round wings, which clearly not favour such oversea dispersal. Furthermore, these birds seems to be very philopatric as shown by a capture-recapture data, two females of $S$. abnormis being retrapped only $800 \mathrm{~m}$ from where they were originally mist-netted several years earlier (Winkler and Christie 2002). Therefore, the Isthmus of Kra Seaways probably have promoted the speciation between these two piculets and we here tentatively dated the $S$. ochracea-S. abnor- mis split to have occurred 5 Myrs BP (as the mean between 4.5 and 5.5).

The applicability of the global molecular clock for all individual data sets was tested using the Likelihood Ratio Test $\left(-2 \ln A=2\left(\ln \lambda_{1}-\ln \lambda_{2}\right)\right.$, where $\lambda_{1}$ is the likelihood of the restricted model) (Huelsenbeck and Rannala, 1997), which follows a Chi-squared distribution with $n-2$ degrees of freedom where $n$ is the number of taxa. Divergence times were estimated using PAML $3.14 \beta$ (Yang 2003). A molecular clock was followed (see below) and we assigned a GTR $+\mathrm{G}$ model to each partition (ND2, myoglobin intron 2 and $\beta$-fibrinogen intron 7) for the dating analysis. The Bayesian tree obtained from the combined analyses of the three genes was used for the molecular clock analysis.

\section{Results}

The concatenation of the three gene regions resulted in a final alignment of $2676 \mathrm{bp}$. From the myoglobin intron 2, we obtained between 646 bp (Dendrocopos minor) and 682 bp (Picoides tridactylus), resulting in an alignment of 686 bp among which 76 were parsimony informative. Both Modeltest (Posada and Crandall 1998) and MrModeltest (Nylander 2004) selected the $\mathrm{K} 80+\mathrm{G}$ model as the best-fit model for the myoglobin data set. The ML parameters estimated by Modeltest were: base frequencies $(\mathrm{A}=\mathrm{C}=\mathrm{G}=\mathrm{T}=0.25)$, ts $/ \mathrm{tv}$ ratio $=2.5088$, $\alpha=0.6309$. Parsimony analyses yielded 16 equally parsimonious trees of 197 steps (consistency index $=0.85$, retention index $=0.89$ ). The strict consensus of the 16 equally parsimonious trees was identical to the Bayesian tree (mean score of the three runs: $-\ln =2197.23, \mathrm{SD}=$ 0.73; Fig. 1). ML analyses yielded one tree $(-\ln =$ 2176.5033) for which the topology only differ at two nodes from the Parsimony and Bayesian trees. These nodes were polytomized in the MP and Bayesian trees and resolved in the ML tree (none of them received significant support). The likelihood ratio test did not reject the hypothesis of a molecular clock for the myoglobin sequences (molecular clock: $-\ln =2182.11$, $-2 \ln A=11.21$, df $=24, \mathrm{P}=0.99$ ).

From the $\beta$-fibrinogen intron 7 , we obtained between $753 \mathrm{bp}$ (Picus canus) and 888 bp (Indicator minor), resulting in an alignment of $968 \mathrm{bp}$. After exclusion of the zone where nucleotide alignment was ambiguous, the $\beta$-fibrinogen intron 7 data set was 954 bp long (261 characters were variable among which 138 were informative). Modeltest and MrModeltest selected the TVM and GTR model as the best-fit models for the $\beta$ fibrinogen data set, respectively. ML parameters for the TVM model estimated by Modeltest were: base

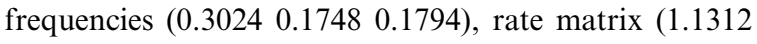
$3.55090 .87312 .15013 .5509)$. Parsimony analyses yielded 2 equally parsimonious trees of 310 steps 
Fig. 1. Bayesian tree $(-\ln =$ 2197.23 $\mathrm{SD}=0.73$ ) obtained from the nuclear myoglobin intron 2 gene under a $\mathrm{K} 80+\mathrm{G}$ model for nucleotide substitutions. Bootstrap proportions and posterior probabilities are indicated as $\mathrm{P} / \mathrm{ML} /$ BI. Asterisks represent bootstrap values/posterior probabilities higher than $90 \%$ and 0.95 , respectively. Dashes indicate that either an alternative node was found or that the node was supported by a bootstrap value/ posterior probabilities lower than $50 \%$ and 0.6 , respectively.

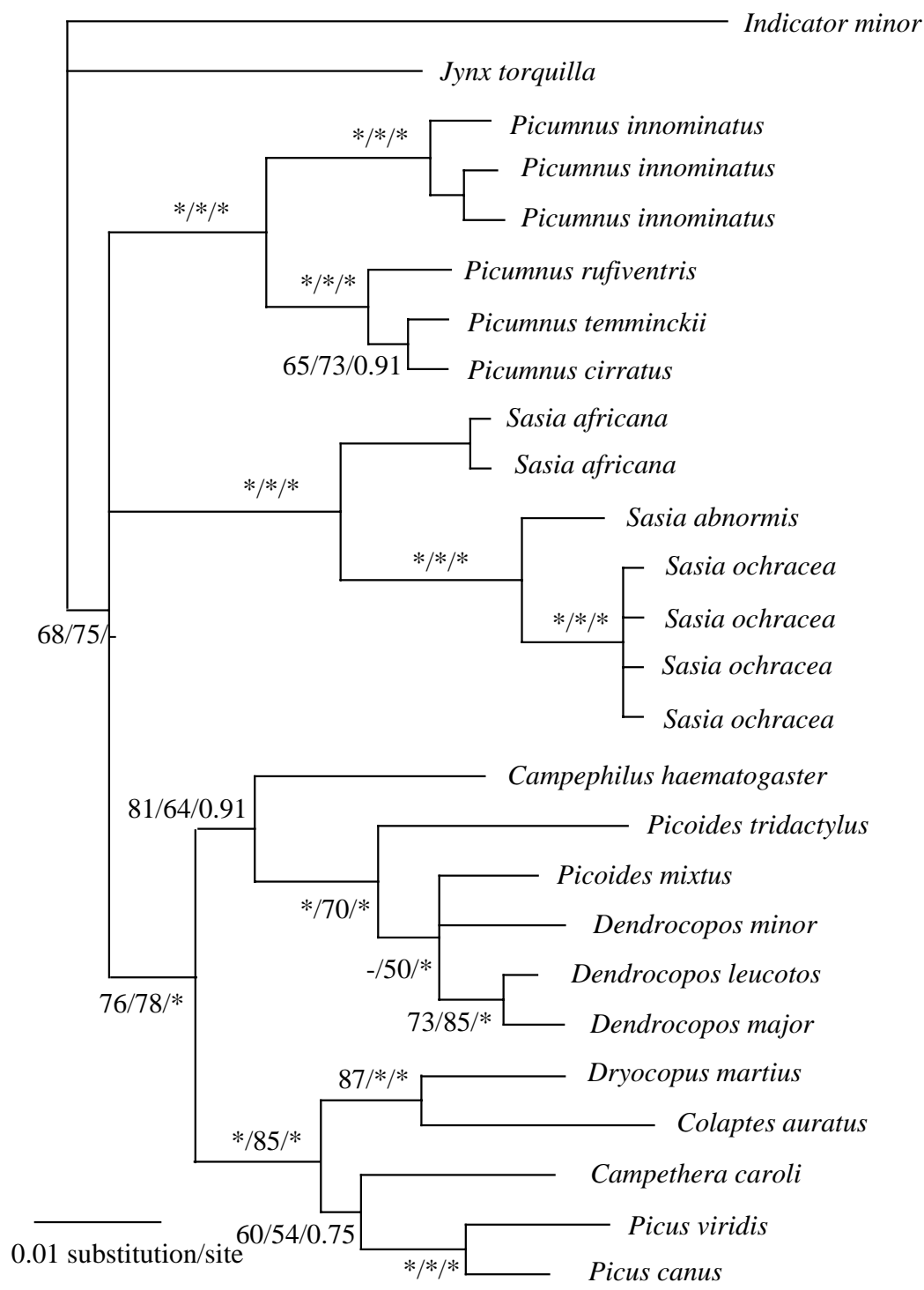

(consistency index $=0.92$, retention index $=0.95$ ). The strict consensus of the 2 equally parsimonious trees was identical to the ML and Bayesian trees (Fig. 2; ML tree: $-\ln =3170.00$, Bayesian mean score of the three runs: $-\ln =3194.93, \mathrm{SD}=0.24)$. The likelihood ratio test did not reject the hypothesis of a molecular clock for the $\beta$-fibrinogen sequences (molecular clock: $-\ln =3180.19$, $-2 \ln A=20.38, \mathrm{df}=25, \mathrm{P}=0.73$ ).

The final alignment for the ND2 gene was 1,036 bp long, corresponding to the positions 5246 to 6281 of the chicken mitochondrial sequence (GenBank accession number X52392, Desjardins and Morais 1990). The number of parsimony informative sites was 445 . Both Modeltest and MrModeltest selected the GTR $+\mathrm{G}+\mathrm{I}$ model for the whole ND2 gene. The GTR $+\mathrm{G}+\mathrm{I}$ model was also selected by MrModeltest for all three codon positions. Modeltest parameters estimates for the ML analysis were as follows: base frequencies $(0.34250 .4317$ $0.0518)$, rate matrix $\left(\begin{array}{lllll}0.1101 & 7.2948 & 0.3164 & 0.0186\end{array}\right.$ $2.4163), \alpha(0.9420)$, and proportion of invariable sites (0.4003). Parsimony analysis yielded one most parsimonious tree of 1660 steps (consistency index $=0.48$, retention index $=0.62$ ) that only differs at one node (the relative positions of Picumnus and Sasia with respect to Picinae) from the ML tree $(-\ln =8299.20)$. In neither case the node in question received bootstrap support. Both the partitioned by codon position (mean score of the three runs: $-\ln =7860.21, \mathrm{SD}=0.26$ ) and non-partitioned (mean score of the three runs: $-\ln =8321.41, \mathrm{SD}=0.16)$ Bayesian analyses recovered similar trees (Fig. 3), the few discrepancies being nodes that were poorly supported, i.e., posterior probabilities 


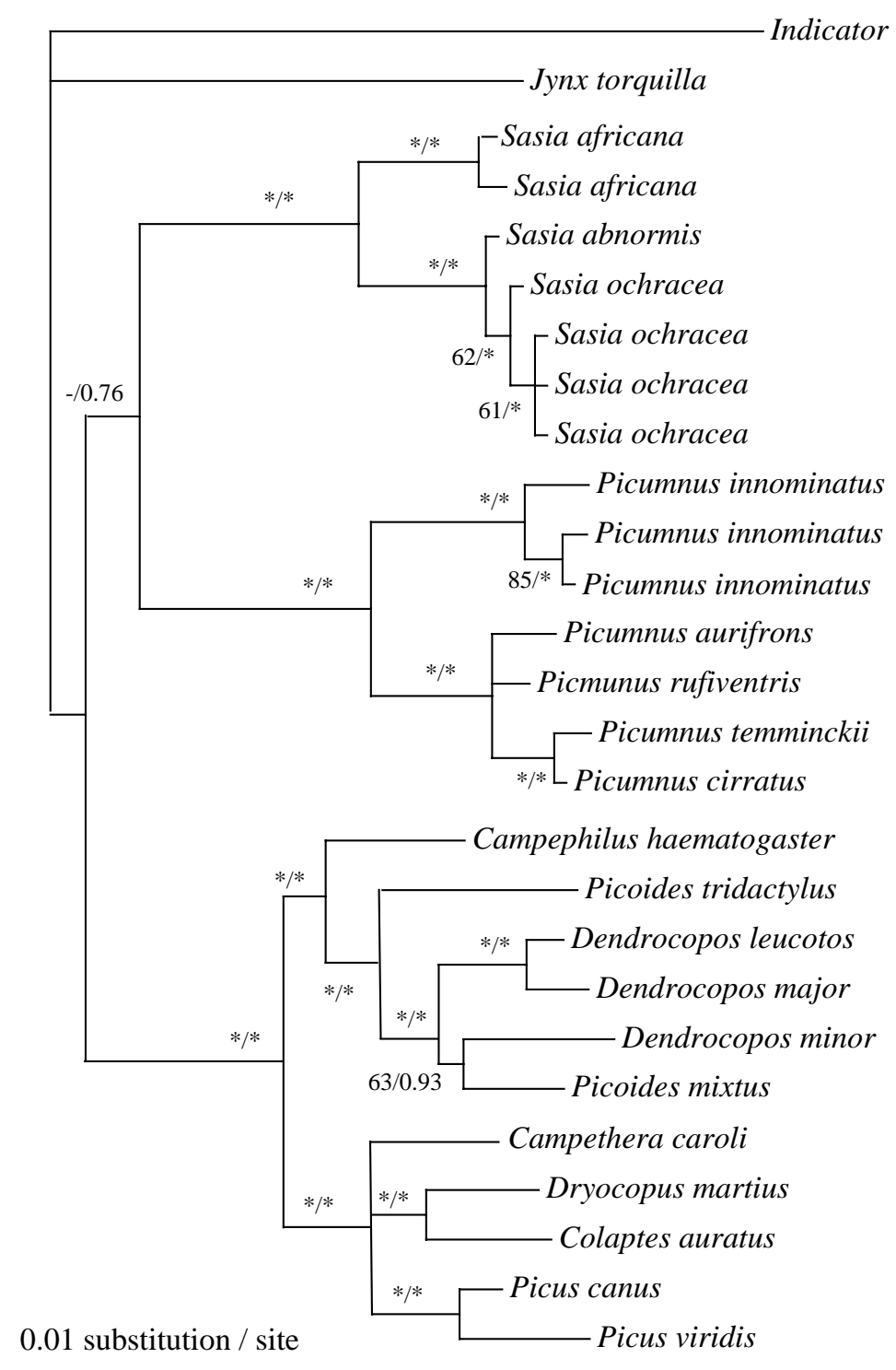

Fig. 2. Bayesian tree $(-\ln =3194.93$, $\mathrm{SD}=0.24$ ) obtained from the nuclear $\beta$-fibrinogen intron 7 under a GTR model for nucleotide substitutions. Bootstrap proportions and posterior probabilities are indicated as $\mathrm{P} / \mathrm{ML} / \mathrm{BI}$. Asterisks represent bootstrap values/ posterior probabilities higher than $90 \%$ and 0.95 , respectively. Dashes indicate that either an alternative node was found or that the node was supported by a bootstrap value/posterior probabilities lower than $50 \%$ and 0.6 , respectively.

0.01 substitution / site

Picus viridis

below 0.6 in one analysis, but collapsed in the other. The likelihood ratio test did not reject the hypothesis of a molecular clock for the ND2 sequences (molecular clock: $-\ln =8314.90,-2 \ln A=31.40, \mathrm{df}=24$, $\mathrm{P}=0.13$ ).

The combined analyses were performed without Picumnus aurifrons as we only had a fibrinogen sequence for this taxon. Parsimony (2,169 steps, 1 most parsimonious tree, consistency index $=0.57$, retention index $=$ 0.70 ), and Bayesian analyses (partitioned by gene: mean of the three runs: $-\ln =13705.32 \mathrm{sd}=0.60$; partitioned by gene and codon position for ND2: mean of the three runs: $-\ln =13244.31 \mathrm{sd}=0.82$ ) of the combined dataset yielded trees that are nearly identical to the individual gene trees (discrepancies concern only nodes that were poorly supported in all analyses, such as the relative positions of Sasia and Picumnus with respect to the Picinae; Fig. 4).

Three main clades were recovered, corresponding to the genus Sasia, genus Picumnus and subfamily Picinae, respectively. These clades were all supported by bootstrap values of $100 \%$ and posterior probabilities of 1.0 (1-4). The mapping of the indels onto the trees reveals that monophyly of Picumnus, Sasia and Picinae were also supported by 2, 3 and 3 synapomorphic indels, respectively. Sasia africana was the sister-group of the two southeast Asian species ( $S$. abnormis and S. ochracea) while the Southeast Asian Picumnus innominatus was the sister-group of the clade composed by the South American Picumnus. Both the African 
Fig. 3. Bayesian tree $(-\ln =$ 8321.41 $\mathrm{SD}=0.16$ ) obtained from the mitochondrial ND2 gene under a GTR $+\mathrm{G}+\mathrm{I}$ model for nucleotide substitutions (non-partitioned by codon position). Bootstrap proportion and posterior probabilities are indicated as $\mathrm{P} / \mathrm{ML} /$ BI non-partitioned/BI partitioned. Asterisks represent bootstrap values/posterior probabilities higher than $90 \%$ and 0.95 , respectively. Dashes indicate that either an alternative node was found or that the node was supported by a bootstrap value/ posterior probabilities lower than $50 \%$ and 0.6 , respectively.

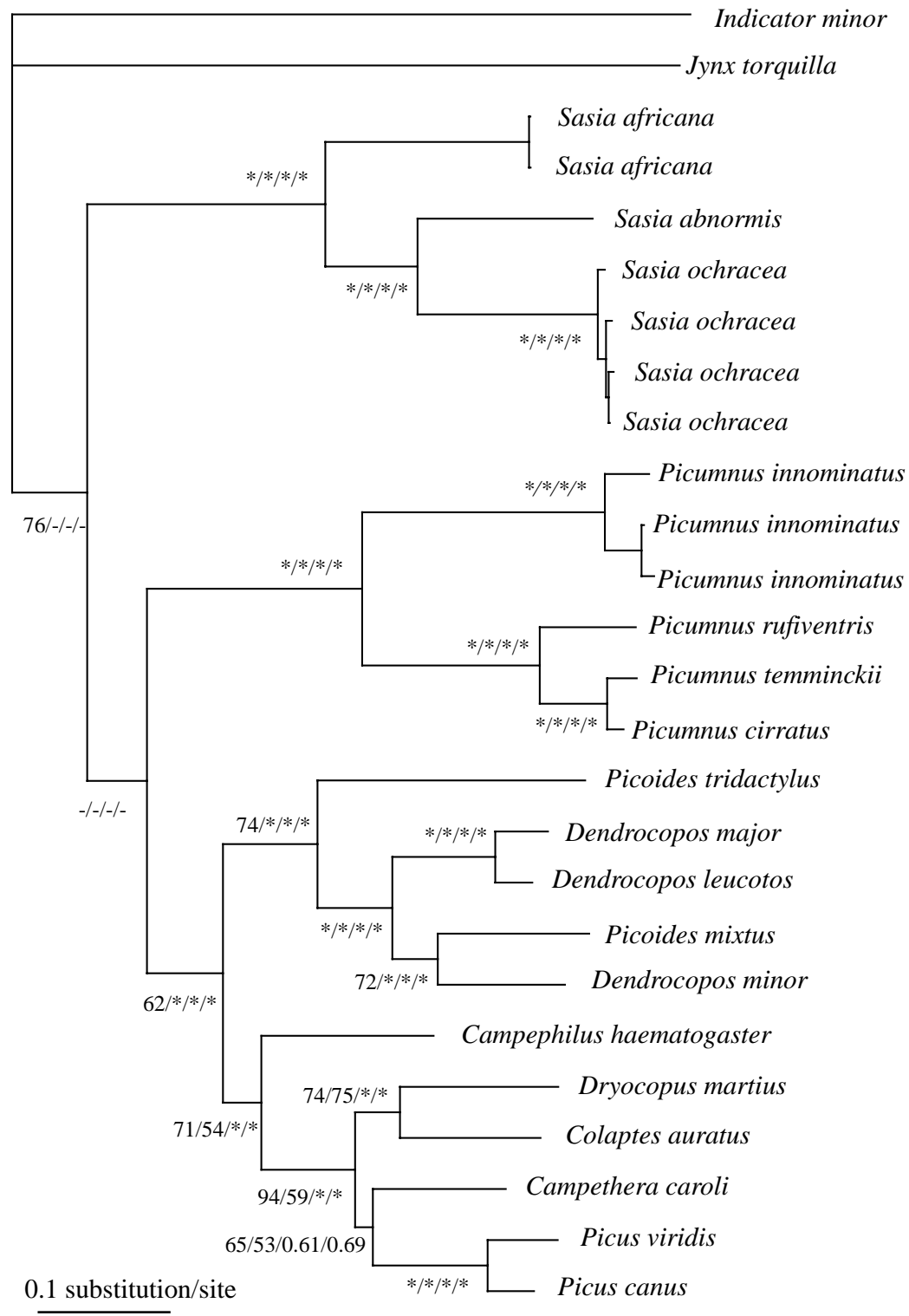

tween these birds (Peters 1948, Wolters 1975-82, Winkler and Christie 2002, Dickinson 2003). None of our analyses strongly recovered the Picumninae as monophyletic. Instead, we found three well differentiated lineages within the Picidae: Picumnus, Sasia and the Picinae. In theory, this result could be due to that our taxonomic sampling did not allow us to test the monophyly of the presumed Sasia-Picumnus clade. This is very unlikely because we sampled several Picinae genera as well as a member of the subfamily Jynginae, the sister-group of the Picumninae-Picinae clade (Swierczewski and Raikow 1981, Prychitko and Moore 2003). An alternative hypothesis is that Sasia and Picumnus do not form a monphyletic assemblage. Non-monophyly of the Sasia-Picumnus clade seems
Monophyly of Picumninae has never been questioned because of the close morphological resemblance be- 


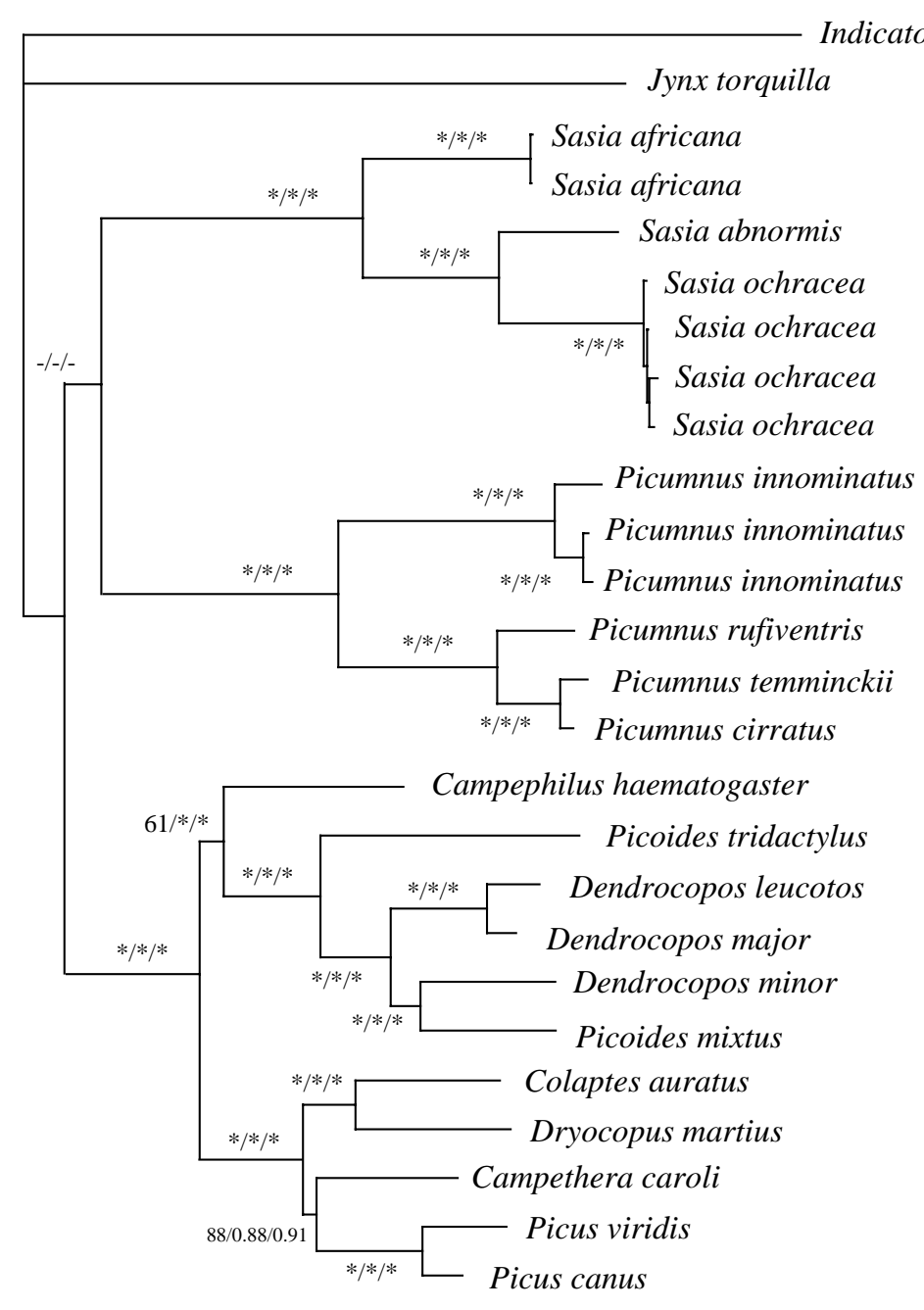

Fig. 4. Bayesian tree $(-\ln =$ 13705.32 $\mathrm{SD}=0.60)$ obtained from the combined data set with the best fit model assigned to each partition (ND2, myoglobin intron 2, $\beta$ fibrinogen intron 7). Bootstrap proportion and posterior probabilities are indicated as $\mathrm{P} / \mathrm{BI}$ partitioned by gene/BI partitioned by codon position. Asterisks represent bootstrap values/ posterior probabilities higher than $90 \%$ and 0.95 , respectively. Dashes indicate that either an alternative node was found or that the node was supported by a bootstrap value/posterior probabilities lower than $50 \%$ and 0.6 , respectively.

0.1 substitution / site

dubious, however, given that this clade is supported by several morphological synapomorphies (e.g. the loss of the coracoid head of the subcoracoideus and the presence of a fleshy insertion of the musculus rhomboideus profundus on the ilium; Goodge 1972). It should be noted that Nesoctites do not possess these two derived characters (Goodge 1972) and its relationships with respect to other piculets need to be further explored. Monophyly of the Sasia-Picumnus clade was also recovered by Webb and Moore (2005) with nearly significant posterior probabilities (0.94). Finally, a third hypothesis would be that Picumninae is in fact monophyletic, and that the Picumnus-Sasia split occurred more or less contemporaneously to the split between Picinae and Picumninae. This may be the most plausible hypothesis because our estimation of the divergence time for the Picumnus-Sasia-Picinae trichotomy is 15.5 Myrs $\mathrm{BP}(\mathrm{SD}=1.3)$, an age contemporary with the Miocene climate optimum (Zachos et al. 2001). The hotter and more humid climate during this period probably favoured the formation of more complex ecological niches leading to more diverse foraging strategies among woodpeckers. Such a scenario is supported by the study of Styring and Hussin (2004) who showed that tropical rain forests in Malaysia offer an increasing variation in micro-habitats and ecological niches available to woodpeckers when compared to more temperate regions. The increased diversification in foraging strategies may in turn have lead to a larger morphological and ethological variation between the three main lineages of woodpeckers leading to the Picumnus, Sasia and Picinae clades of today. Possibly, the systematic relationships between these lineages could be resolved by adding more sequence data and more taxa, especially the Antillean piculet (Nesoctites micromegas). 


\section{Picumnus}

Monophyly of this genus has never been questioned but its pantropical distribution is unusual among birds and this has been used as an argument to recognize the genus Vivia for the Asian species. The merging of Vivia with Picumnus is supported by the general colouration pattern share, the laterally converging white bars on the outer tails feather and the white stripe on the central feather. Two other, often cited cases of pantropical distributions at the genus level in birds, Celeus (Picidae) and Spizaetus (Accipitridae; Dickinson 2003), may not be correct as both Celeus and Spizaetus are polyphyletic (Bunce et al. 2005, Lerner and Mindell 2005, Fuchs et al. unpub. data). The situation in Picumnus may thus be unique among birds. Our data strongly supported the monophyly of the genus Picumnus but the genetic distances between the Asian species and the four South American species are larger than those observed between traditionally recognized Picinae genera (see below). Given these data, retaining $P$. innominatus in the genus Vivia Hodgson, 1837 would appear, at a first instance, rather logical, but we do not advocate such a change as no morphological synapomorphy clearly define the remaining Picumnus. Our taxonomic sampling of South American Picumnus is also limited (four species representing three different superspecies). However, we can rule out the the Asian species is embedded within the New World radiation because the diversification of Picumnus in South American seems to be a rather recent event, as inferred from the several species complex (superspecies) currently recognized (e.g. Winkler and Christie 2002). Our estimation of the date of the first split within the two main South American lineages (3.0 Myr BP, sd =0.04) suggests that the radiation of Picumnus in South America is attributable to the PlioPleistocene climatic oscillations and formations of river barriers throughout the Amazonian basin. As a consequence, we are confident that the Asian Picumnus represents a relict species that is the sister-group of the New World Picumnus radiation.

\section{Sasia}

The genus Sasia includes three species of tiny woodpeckers with disrupted distribution as one species ( $S$. africana) is endemic to tropical Africa while the remaining two species ( $S$. abnormis and $S$. ochracea) inhabits the Indo-Malayan Region. Due to some peculiar morphological differences such as number of toes and tail feathers (Short 1988), the African species was sometimes retained in its own genus, Verreauxia Hartlaub, 1856 (Peters 1948). All our analyses strongly supported the monophyly of the genus Sasia although the split between the African and the two Asian representatives is ancient (estimated herein to 7.9 Myrs $\mathrm{BP}$ ). In fact, this predates the splits between many traditionally recognized genera in Picinae, e.g., the split between Dryocopus and Colaptes which is here estimated to have occurred 5.2 Myr BP, $\mathrm{SD}=0.5$. Based both on morphological and genetic distinctness we resurrect the genus Verreauxia Hartlaub, 1856, for the African Piculet. The genus Verreauxia is defined by its lower number of rectrices (eight in Verreauxia versus ten in all other woodpeckers).

\section{Biogeography}

The identical estimates of the dating of the divergence between the African and Asian Sasia and the split between the Old World and New World Picumnus (7.9 Myr BP) suggests that the same external factor promoted the differentiation of these groups. The time estimates correspond to the start of the period of formation of the Northern Hemisphere ice sheet. The drier conditions may in turn have promoted the expansion of grasslands and the diversification of the $\mathrm{C} 4$ grasses (Zachos et al. 2001). The expanding grasslands resulted in large, non-forested areas in Eurasia and North America that prevented gene flow between tropical forest birds as the piculets in Southeast Asia and Africa on one hand, and Southeast Asia and South America on the other.

Acknowledgements - We are grateful to Paul Sweet and Joel Cracraft (American Museum of Natural History, New York), Donna L. Dittmann, Robb T. Brumfield and Frederic H. Sheldon (Louisiana State University, Museum of Natural History, Baton-Rouge), Jon Fjeldså and Jan Bolding Kristensen (Zoological Museum, University of Copenhagen) for providing some of the samples we used. To Annie Tillier, Céline Bonillo, and Josie Lambourdière for technical help during laboratory works at MNHN and to Dario Zuccon for assistance in the Molecular Systematics Laboratory in Stockholm. The Phongsaly Forest Conservation and Rural Development Project, a Lao-European cooperation and its staff, especially Philippe Rousseau, Dr. Christopher Hatten, Yiannis Varelides, Richard Humphrey and $\mathrm{Mr}$ Tipavanh are thanked for their assistance and support to J. F. during fieldwork. The Museo Nacional de Historia Natural del Paraguay, San Lorenzo, and its staff are thanked for collaboration during joint fieldwork in Paraguay for which the Direccion de Parques Nacional y Vida Silvestre issued necessary collecting and export permits. Laboratory work at MNHN was supported by the 'Service Commun de Systématique Moléculaire', IFR CNRS 101, MNHN, and at NRM by the Swedish Research Council (grant no. 621-2004-2913 to P.G. P. Ericson).

\section{References}

Bunce, M., Szulkin, M., Lerner, H. R. L., Barnes, I., Shapiro, B., Cooper, A. and Holdaway, R. N. 2005. Ancient DNA provides new insights into the evolutionary history of New Zealand's extinct Giant Eagle. - PLOS Biology 3: e9.

Dickinson, E. C. (Ed). 2003. The Howard and Moore complete checklist of the birds of the world, 3rd edition. - Princeton University Press, Princeton, New Jersey.

Desjardins, P. and Morais, R. 1990. Sequence and gene organization of the chicken mitochondrial genome a novel 
gene order in higher vertebrates. - J. Mol. Biol. 212: 599634.

Felsenstein, J. 1985. Confidence limits of phylogenies: an approach using the bootstrap. - Evolution 39: 783-791.

Fuchs, J., Bowie, R. C. K., Fjeldså, J. and Pasquet, E. 2004. Phylogenetic relationships of the African bush-shrikes and helmet-shrikes (Passeriformes: Malaconotidae). - Mol. Phylogenet. Evol. 33: 428-439.

Guindon, S. and Gascuel, O. 2003. A simple, fast and accurate algorithm to estimate large phylogenies by maximum likelihood. - Syst. Biol. 52: 696-704.

Goodge, W.R. 1972. Anatomical evidence for phylogenetic relationships among woodpeckers. - Auk 89: 65-85.

Heslewood, M. M., Elphinstone, M. S., Tidemann, S. C. and Baverstock, P. R. 1998. Myoglobin intron variation in the Gouldian finch Erythrura gouldiae assessed by temperature gradient gel electrophoresis. - Electrophoresis 19: 142-151.

Huelsenbeck, J. P. and Rannala., B. 1997. Phylogenetic methods come of age: testing hypotheses in an evolutionary context. - Science 276: 227-232.

Huelsenbeck, J. P. and Ronquist, F. 2001. MrBayes: bayesian inference of phylogenetic trees. - Bioinformatics 17: 754 755.

Johansson, U. S. and Ericson, P. G. P. 2003. Molecular support for a sister group relationship between Pici and Galbulae (Piciformes sensu Wetmore 1960). - J. Avian Biol. 34: 185197.

Laybourne, R. C., Deedrick, D. W. and Hueber, F. M. 1994. Feather in amber is earliest New World fossil of Picidae. - Wilson Bull. 106: 18-25.

Lerner, H. R. L. and Mindell, D. P. 2005. Phylogeny of eagles, Old World vultures, and other Accipitri based on nuclear and mitochondrial DNA. - Mol. Phylogenet. Evol. 37: 237-346

Mayr, G. 2001. The earliest fossil record of a modern-type piciform birds from the late Oligocene of Germany. - J. Ornithol. 142: 2-6.

Mayr, G. and Smith, R. 2001. Ducks, rails, and limicoline waders (Aves: Anseriformes, Gruiformes, Charadiiformes) from the lowermost Oligocene of Belgium. - Geobios-Lyon 34: $547-561$.

Nylander, J. A. A. 2004. MrModeltest 2.0. Program distributed by the author. - Evol. Biol. Centre, Uppsala University.

Peters, J. L. 1948. Check-list of the birds of the World Volume VI. - Harvard University Press, Cambridge.

Posada, D. and Crandall, K. A. 1998. ModelTest 3.06: testing the model of DNA substitution. - Bioinformatics 14: 817818.

Prychitko, T. M. and Moore, W. S. 1997. The utility of DNA sequences of an intron from the beta-fibrinogen gene in phylogenetic analysis of woodpeckers (Aves: Picidae). - Mol. Phylogenet. Evol. 8: 193-204.

Prychitko, T. M. and Moore, W. S. 2000. Comparative evolution of the mitochondrial cytochrome $\mathrm{b}$ gene and nuclear betafibrinogen intron 7 in woodpeckers. - Mol. Biol. Evol. 17: $1101-1111$.

Prychitko, T. M. and Moore, W. S. 2003. Alignment and phylogenetic analysis of $\beta$-Fibrinogen intron 7 sequences among avian orders reveal conserved regions within the intron. - Mol. Biol. Evol. 20: 762-771.

Short, L. L. 1982. Woodpeckers of the world. - Delaware Museum of Natural History, Greenville, Delaware.

Short, L. L. 1988. Picidae, woodpeckers, piculets and wrynecks. - In: Fry, C.H., Keith, S. and Urban, C.K. (eds). Birds of Africa. Vol. III. Academic Press, London.

Sibley, C. G. and Ahlquist, J. E. 1990. Phylogeny and classification of birds: a study in molecular evolution. - Yale University Press, New Haven, Connecticut.

Simpson, S. F. and Cracraft, J. 1981. The phylogenetic relationships of the Piciformes (Class Aves). - Auk 98: 481-494.

Slade, R. W., Moritz, C., Heideman, A. and Hale, P. T. 1993. Rapid assessment of single-copy nuclear DNA variation in diverse species. - Mol. Ecol. 2: 359-373.

Sorenson, M. D., Ast, J. C., Dimcheff, D. E., Yuri, T. and Mindell, D. P. 1999. Primers for a PCR-based approach to mitochondrial genome sequencing in birds and other vertebrates. - Mol. Phylogenet Evol. 12: 105-114.

Sorenson, M. D. and Quinn, T. W. 1998. Numts: a challenge for avian systematics and population biology. - Auk 115: $214-$ 221.

Styring, A. R. and bin Hussin, M. Z. 2004. Foraging ecology of woodpeckers in lowland Malaysian rain forests. - J. Trop. Ecol. 20: 487-494

Swofford, D. L. 2001. PAUP*: Phylogenetic Analysis Using Parsimony (* and other methods) 4.0b10. Sinauer Associates Sunderland, Massachusets.

Swierczewski, E. V. and Raikow, R. J. 1981. Hind limb morphology, phylogeny and classification of the Piciformes. - Auk 98: 466-480.

Webb, D. M. and Moore, W. S. 2005. A phylogenetic analysis of woodpeckers and their allies using $12 \mathrm{~S}$, Cyt b, and COI nucleotide sequences (class Aves; order Piciformes). - Mol. Phylogenet. Evol. 36: 233-248.

Weibel, A. C. and Moore, W. S. 2002. A test of a mitochondrial gene-based phylogeny of woodpeckers (genus Picoides) using an independent nuclear gene, beta-fibrinogen intron 7. - Mol. Phylogenet. Evol. 22: 247-257.

Winkler, H. and Christie, D. A. 2002. Family Picidae (Woodpeckers). In: Handbook of the Birds of the World. Volume 7. Jacamars to Woodpeckers. Lynx Edicions, Barcelona.

Winnepenninckx, B., Backeljau, T. and De Wachter, R. 1993. Extraction of high molecular weight DNA from molluscs. - Trends Genet. 9: 407.

Woodruff, D.S. 2003. Neogene marine transgressions, palaeogeography and biogeographic transitions on the Thai-Malay Peninsula. - J. Biogeogr. 30: 551-567.

Yang, Z. 2003. PAML 3.14ß: Phylogenetic analysis by Maximum Likelihood Version 3.14. Available from ftp://abacus. gene.ucl.ac.uk/pub/paml.

Zachos, J., Pagani, M., Sloan, L., Thomas, E. and Billups, K. 2001. Trends, rhythms, and aberrations in global climate change 65 Ma to present. - Science 292: 686-693.

(Received 22 July 2005, revised 7 September 2005, accepted 12 September 2005.) 